от скорости клубочковой фильтрации (СКФ). В 91 (86,67 \%) обследованного больного выявлены признаки системного воспалительного процесса, которые усугубляются со снижением СКФ $<90$ мл/мин. Снижение упругоэластичных свойств артерий с увеличением ИЖА, СРПВ, САVI, уровня ендотелинемии и снижением ЭЗВД и ЭНВД отмечалось у 87 (82,86 \%) больных на ХПН с АГ. В указанной выше категории больных наблюдается корреляционная связь между показателями системного воспалительного ответа (СРП, ФНО- $\alpha$, ИЛ-1 $\beta$, ИЛ- 6, ММА-1) и маркерами эндотелиальной дисфункции (ЭЗВД, ЭНВД, CAVI), который усиливается при снижении скорости клубочковой фильтрации, что следует учитывать при лечении таких больных.

Ключевые слова: хронический пиелонефрит, артериальная гипертензия, системное воспаление, эндотелиальная дисфункция, скорость клубочковой фильтрации.

\title{
A RELATION OF THE INDICES OF SYSTEMIC INFLAMMATION AND ENDOTHELIAL DYSFUNCTION IN PATIENTS WITH CHRONIC PYELONEPHRITIS AND ARTERIAL HYPERTENSION
}

\section{O.R. Luchko}

Abstract. The dynamics of the indicators of systemic inflammation (C-reactive protein - CRP, tumor necrosis factoralpha - TNF- $\alpha$, IL-1 - IL-1, IL-6 - IL-6, soluble cell-cell adhesion molecule - sICAM-1) and endothelial dysfunction (pulse blood pressure - PBP, aortic stiffness index - ASI, the thickness of intima-media complex - TIMC, the velocity of the pulse wave propagation - VPWP, CAVI, endothelium dependent vasodilatation - EDVD and endothelium independent vasodilatation - EIVD, endothelin-1 - ET-1) in 105 patients with chronic pyelonephritis (CPN) and arterial hypertension (AH), depending on the glomerular filtration rate (GFR). 91 (86,67\%) patients have demonstrated the signs of a systemic inflammation which intensify with decreased GFR $<90 \mathrm{ml} / \mathrm{min}$. Reduced resilient- elastic properties of the arteries with increased ASI, VPW, CAVI, the levels of endothelinemia and a decrease of EDVD and EIVD was noted in $87(82,86 \%)$ patients with CPN and AH. The authors have observed a correlation between the indicators of the systemic inflammatory response (CRP, TNF- $\alpha$, IL-1 $\beta$, IL-6, sICAM-1) and the markers of the endothelial dysfunction (EDVD, EIVD, CAVI) in the group mentioned above which increases with a decrease of the glomerular filtration rate which should be considered, when treating such patients.

Key words: chronic pyelonephritis, hypertension, systemic inflammation, endothelial dysfunction, glomerular filtration rate.

SHEE "National Medical University (Ivano-Frankivs'k)"

Рецензент - проф. Л.Д. Зуб

Buk. Med. Herald. - 2013. - Vol. 17, № 1 (65). - P. 59-64

Надійшла до редакції 10.12.2012 року

(C) О.Р. Лучко, 2013

УДК 612.017.582.284.

\section{О.М. Макаренко, М.П. Рудик, В.В. Позур, М.М. Сухомлин, В.М. Святецька, Р.С. Довгий \\ ВПЛИВ КУЛЬТУРАЛЬНОЇ РІДИНИ ТА ЕКСТРАКТУ МІЦЕЛІЮ \\ ГРИБА LEUCOAGARICUS MACRORHIZUS НА КИСНЕЗАЛЕЖНИЙ МЕТАБОЛІЗМ ПЕРИТОНЕАЛЬНИХ МАКРОФАГІВ МИШЕЙ}

ННЦ «Інститут біології» Київського національного університету імені Тараса Шевченка

Резюме. Досліджували вплив культуральної рідини і екстракту міцелію гриба Leucoagaricus macrorhizus на киснезалежний метаболізм перитонеальних макрофагів мишей. Показано, що культуральна рідина впливала на показники киснезалежного метаболізму досліджуваних фагоцитувальних клітин. Найбільший ефект проявляли концентрації 100 і 200 мкг/мл, підвищуючи киснезалежний метаболізм на 168 \% і 143 \% відповід-

Вступ. Важливим напрямом досліджень у наш час $€$ визначення можливості застосування препаратів грибів як лікувальних засобів при онкологічних захворюваннях. Одним із механізмів інгібування росту пухлин екстрактами грибів $\epsilon$ підсилення функцій неспецифічного та адаптивного імунітету [7, 11]. Найбільш вивченими видами

(C) О.М. Макаренко, М.П. Рудик, В.В. Позур,

М.М. Сухомлин, В.М. Святецька, Р.С. Довгий, 2013 но. Екстракт міцелію в концентрації 50 мкг/мл знижував киснезалежний метаболізм на 11 \% порівняно 3 контролем, додавання інших концентрацій не викликало вірогідних змін.

Ключові слова: Leucoagaricus macrorhizus, культуральна рідина, екстракт міцелію, перитонеальні макрофаги, киснезалежний метаболізм.

грибів, які містять біологічні речовини, що здатні стимулювати імунну систему та пригнічувати розвиток новоутворень, є Ganoderma lucidum (рейші), Cordyceps sinensis, Lentinus edodes (шиітаке), Grifola frondosa (мейтаке), Hericium erinaceus та Agaricus blazei (химемацутаке) [8]. 
Leucoagaricus macrorhizus - вид, занесений до Червоної Книги України, нещодавно уведений у культуру. Відомості щодо його впливу на імунну систему в літературі відсутні.

Цитотоксична дія, заснована на продукції активних форм кисню, властива широкому спектру клітин організму, серед яких особливе значення належить макрофагам. Макрофаги локалізовані переважно в тканинах $[1,9,10]$. У системі мононуклеарних фагоцитів макрофаги виконують функцію санітарів організму: розпізнають, поглинають і знешкоджують або лізують різні чужорідні агенти, а також власні клітини зі зміненими поверхневоклітинними молекулами, наприклад, у результаті загибелі їх шляхом апоптозу [6]. У відповідь на фагоцитоз патогенів або на контакт із розчинними патоген-асоційованими молекулами, а також прозапальними цитокінами, у макрофагів розвивається система реакцій, яка має загальну назву «кисневий вибух» і в результаті якої утворюється моновалентна похідна молекулярного кисню - супероксид-аніон. Наслідком наступних реакцій є поява інших токсичних метаболітів, таких, як перекис водню, гіпохлориста кислота (HOCI), гідроксил-радикал та синглетний кисень.

Мета дослідження. Дослідити вплив екстрактів гриба L. macrorhizus на киснезалежний метаболізм перитонеальних макрофагів мишей.

Матеріал і методи. Для експериментів використовували водні екстракти міцелію та культуральну рідину штаму ТТ-1 Leucoagaricus macrorhizus 3 колекції чистих культур базидіоміцетів кафедри ботаніки ННЦ «Інститут біології» Київського національного університету імені Тараса Шевченка. Тварин утримували в стандартних умовах віварію 3 вільним доступом до води та корму. Усі дослідження на тваринах здійснювали згідно із нормами, встановленими законом України № 3447-IV «Про захист тварин від жорстокого поводження» і норм, прийнятих в Свропейській конвенції із захисту хребетних тварин, яких використовують для експериментальних і наукових цілей від 20.09.1985 [5]. Культуру грибів отримували тканинним методом шляхом перенесення фрагментів плодових тіл на поверхню агаризованого картопляно-глюкозного середовища в чашках Петрі. Міцелій грибів та культуральну рідину одержували в пласкодонних скляних колбах на 100 мл на рідкому картопляноглюкозному середовищі. Для отримання екстракту міцелію гриба L. macrorhizus плодове тіло гриба розтирали в ступі для отримання гомогенної субстанції.

Для отримання перитонеальних макрофагів мишей тваринам у черевну порожнину уводили по 5 мл середовища Хенкса та проводили масаж передньої стінки черевної порожнини. Потім відбирали суспензію клітин, що утворилася, та відмивали клітини (1500 об/хв, 10 хв) [2]. Осад ресуспендували в 1 мл середовища Хенкса та доводили кінцеву концентрацію клітин до $3 \times 10^{6}$ клітин/мл. Кількість життєздатних клітин підраховували за стандартною методикою, використовуючи суправітальне забарвлення трипановим синім.

Функціональну активність визначали за відновленням нітросинього тетразолію (НСТ). НСТтест проводили згідно 3 методикою Передерій В.Г. та ін. [3]. 100 мкл клітин перитонеального ексудату вносили в плоскодонний планшет у концентрації $3 \times 10^{5}$ у ямку. Інкубували впродовж 30 хв при $37^{\circ} \mathrm{C}$ для забезпечення адгезії макрофагів до поверхні пластика. У проби додавали 0,01 мл НСТ у концентрації 5 мкг/мл, та гриб у трьох концентраціях: 50 мкг/мл, 100 мкг/мл та 200 мкг/ мл. У дослідні ямки вносили по 20 мкл екстракту. Інкубували 15 хв при $37^{\circ} \mathrm{C}$. Після чого осаджували клітини центрифугуванням при 1500 об/хв упродовж 10 хв. Супернатант відбирали. Реакцію відновлення НСТ зупиняли додаванням 0,1 мл $2 \mathrm{M} \mathrm{KOH}+0,1$ мл $50 \%$ р-ну диметилсульфоксиду. Оптичну густину диформазану визначали на мікроплейтфотометрі типу "Reader" (Лаботек, Латвия) при довжині хвилі 630 нм.

Статистичну обробку отриманих результатів проводили загальноприйнятими методами варіаційної статистики з розрахунком середнього значення (М), середнього квадратичного відхилення (б) та середньої квадратичної похибки (m). Для визначення вірогідності відмінності показників між дослідом та контролем використовували tкритерій Стьюдента [4].

Результати дослідження та їх обговорення. Додавання культуральної рідини гриба L. macrorhizus у всіх концентраціях призводило до підвищення киснезалежного метаболізму перитонеальних макрофагів мишей (рис. 1). Додавання гриба в концентрації 50 мкг/мл призводило до підвищення киснезалежного метаболізму на 76 \% порівняно 3 контролем. При додаванні культуральної рідини гриба в концентрації 100 мкг/мл спостерігалося підвищення киснезалежного метаболізму на 168 \% порівняно 3 контролем. Застосування культуральної рідини гриба в концентрації 200 мкг/мл призводило до підвищення киснезалежного метаболізму на 143 \%.

Реакція перитонеальних макрофагів на додавання екстракту міцелію L. macrorhizus була іншою.

Додавання екстракту міцелію гриба в концентрації 50 мкг/мл призводило до зниження киснезалежного метаболізму на $11 \%$ порівняно $з$ контролем (рис. 2). Додавання екстракту міцелію гриба в концентрації 100 мкг/мл та 200 мкг/мл не призводило до вірогідних змін показників киснезалежного метаболізму. Можна припустити, що екстракт міцелію гриба in vivo може здійснювати протилежний вплив на макрофаги не безпосередньо, а опосередковано. Наприклад, через активацію Т-хелперами. 


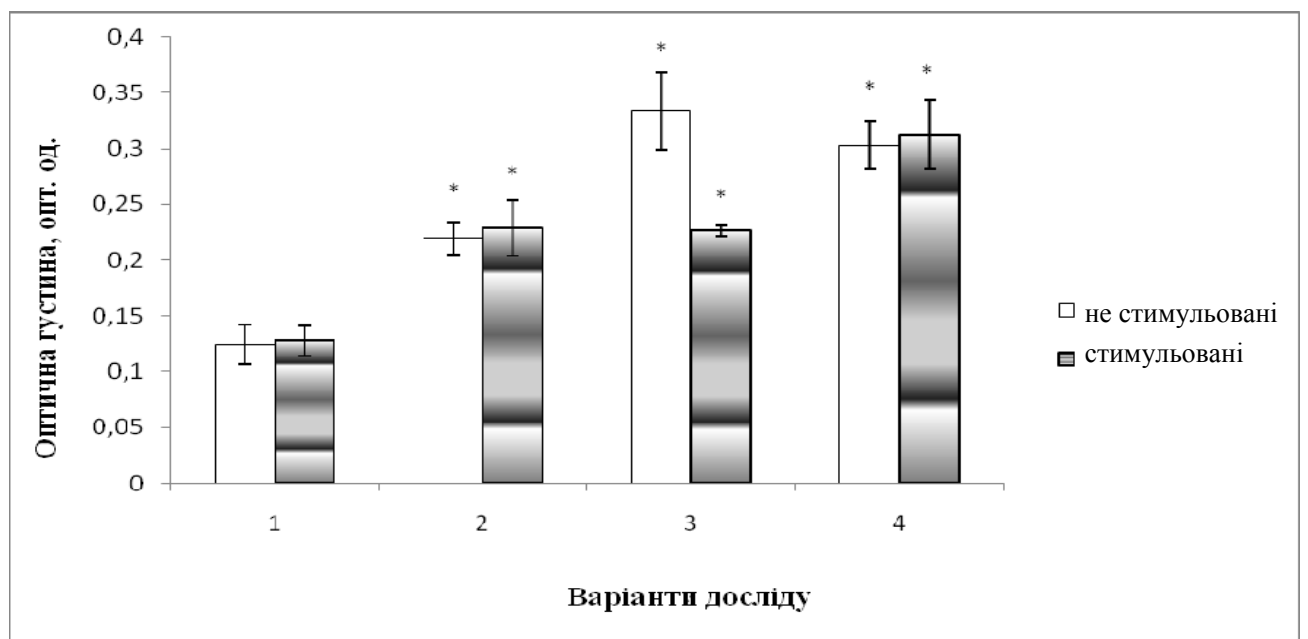

Рис. 1. Вплив культуральної рідини гриба L. macrorhizus на киснезалежний метаболізм перитонеальних макрофагів мишей

Примітка. 1 - контроль; 2 - додавання культуральної рідини гриба L. macrorhizus у концентрації 50 мкг/мл; 3 - додавання культуральної рідини гриба L. macrorhizus у концентрації 100 мкг/мл; 4 - додавання культуральної рідини гриба L. macrorhizus у концентрації 200 мкг/мл; * - p<0,05 порівняно з показниками контрольної групи

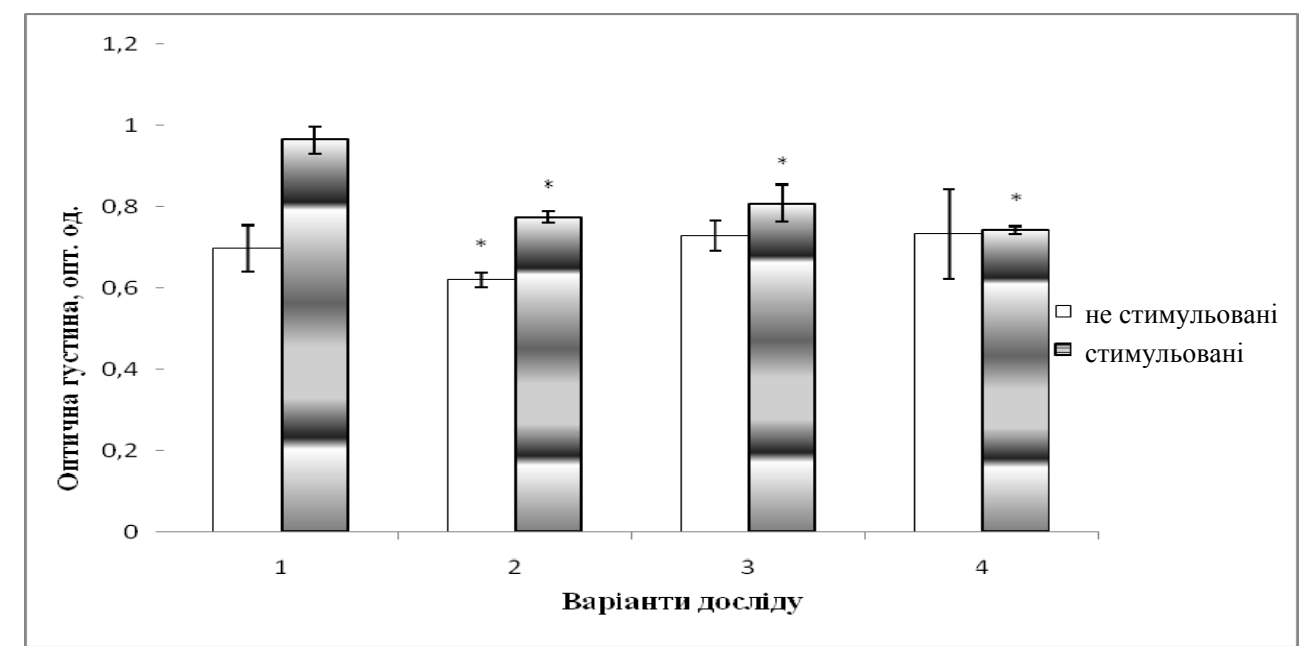

Рис. 2. Вплив екстрактів міцелію гриба L. macrorhizus на киснезалежний метаболізм перитонеальних макрофагів мишей

Примітка. 1 - контроль; 2 - додавання екстракту міцелію гриба L. macrorhizus у концентрації 50 мкг/мл; 3 - додавання екстракту міцелію гриба L. macrorhizus у концентрації 100 мкг/мл; 4 - додавання екстракту міцелію гриба L. macrorhizus у концентрації 200 мкг/мл; * - p <0,05 порівняно з показниками контрольної групи

\section{Висновок}

Додавання культуральної рідини гриба $L$. macrorhizus впливало на киснезалежний метаболізм перитонеальних макрофагів мишей. Найефективнішими дозами виявилися 100 та 200 мкг/мл, що стимулювали «кисневий вибух» перитонеальних макрофагів мишей на 168 \% та 143 \% відповідно, порівняно з контролем. При додаванні екстракту міцелію гриба у концентрації 50 мкг/мл спостерігалося зниження киснезалежного метаболізму, при додаванні екстракту міцелію в інших концентраціях вірогідних змін не спостерігалося.

Перспективи подальших досліджень. Подальші дослідження будуть зосереджені на виділенні і дослідженні окремих діючих речовин 3 культуральної рідини даного гриба і визначенні найбільш ефективних із них.

\section{Література}

1. Вершигора А.Ю. і співавт. Імунологія. - К.: Вища шк., 2005. - 599 с.

2. Иммунологические методы / Под ред. Г.Ф. Фримеля; пер. с нем. - М.: Медицина, 1987. -472 c.

3. Передерій В.Г. Основи внутрішньої медицини / В.Г. Передерій, С.М. Ткач. - К.: Нова Книга, 2010. - 1006 с.

4. Реброва О.Ю. Статистический анализ медицинских данных / О.Ю. Реброва. - М.: МедиаCфера, 2002. - 312 c.

5. Рєзников О. Проблеми етики при проведенні експериментальних медичних i біологічних досліджень на тваринах / О. Рєзников // Вісн. НАН України. - 2001. - № 1. - С. 5-7. 
6. Forman H.J. Signaling by the respiratory burst in macrophages / H.J. Forman, M. Torres // IUBMB Life. - 2001. - № $51 \quad$ (6). P. 365-371.

7. Ko K. M.Y. Enhancement of ATP generation capacity, antioxidant activity and immunomodulatory activities by Chinese Yang and Yin tonifying herbs / K.M. Ko, H.Y. Leung // Chin Med. - 2007. - Vol. 2. - P. 1-3.

8. Lakhanpal T.N. Medicinal and nutraceutical genetic resources of mushrooms / T.N. Lakhanpal, Monika Rana // Plant. Genet. Resour.: Charact. and Util. - 2005. - № 2. - P. 288-303.
9. Moilanen E. Nitric oxide in inflammation and immune response / E. Moilanen, H. Vapaatalo // Ann. Med. - 1995. - № 27 (3). - P. 359-367.

10. Macrophages aquie neutrophil granules for antimicrobal activity against inracellular pathogens / B.H. Tan, C. Meincen, M. Bastian [et al.] // J. Imunol. - 2006. - № 177. - P. 1864-1871.

11. Zhu X. Modulation of cytokines production, granzyme B and perforin in murine CIK cells by Ganoderma lucidum polysaccharides / X. Zhu, Z. Lin // Carbohyd. Polym. - 2006. - Vol. 63. P. 188-197.

\title{
ВЛИЯНИЕ КУЛЬТУРАЛЬНОЙ ЖИДКОСТИ И ЭКСТРАКТА МИЦЕЛИЯ ГРИБА LEUCOAGARICUS MACRORHIZUS НА КИСЛОРОДЗАВИСИМЫЙ МЕТАБОЛИЗМ ПЕРИТОНЕАЛЬНЫХ МАКРОФАГОВ МЫШЕЙ
}

\section{А.Н. Макаренко, М.П Рудык., В.В. Позур, М.Н. Сухомлин, В.Н. Святецкая, Р.С. Довгий}

Резюме. Исследовали влияние культуральной жидкости и экстракта мицелия гриба Leucoagaricus macrorhizus на кислородзависимый метаболизм перитонеальных макрофагов мышей. Показано, что культуральная жидкость влияла на показатели кислородзависимого метаболизма исследуемых фагоцитирующих клеток. Наибольший эффект оказывали концентрации 100 и 200 мкг/мл, повышая кислородзависимый метаболизм на 168 \% и 143 \% соответственно. Экстракт мицелия в концентрации 50 мкг/мл понижал кислородзависимый метаболизм на $11 \%$ по сравнению с контролем, добавление других концентраций не вызывало достоверных изменений.

Ключевые слова: Leucoagaricus macrorhizus, культуральная жидкость, экстракт мицелия, перитонеальные макрофаги, кислородзависимый метаболизм.

\section{THE EFFECT OF THE CULTURAL MEDIUM AND A MYCELIUM EXTRACT OF THE MUSHROOM LEUCOAGARICUS MACRORHIZUS ON OXYGEN-DEPENDENT METABOLISM OF PERITONEAL MACROPHAGES OF MICE}

\author{
O.M. Makarenko, M.P. Rudyk, V.V. Pozur, M.M. Sukhomlin, V.M. Sviatets'ka, R.S. Dovgyi
}

Abstract. The effect of the cultural medium and an extract of mycelium of the Leucoagaricus macrorhizus mushroom on the oxygen dependent metabolism of peritoneal macrophages of mice has been investigated. It has been shown that the cultural medium influenced on the indices of the oxygen dependent metabolism of the phagocytic cells under study. The greatest effect was demonstrated by the cultural medium in a concentration of 100 and $200 \mu \mathrm{g} / \mathrm{ml}$, raising the oxygendependent metabolism by $168 \%$ and $143 \%$ respectively. An extract of mycelium in a concentration of $50 \mu \mathrm{g} / \mathrm{ml}$ lowered the oxygen-dependent metabolism by $11 \%$ compared to the control value, an addition of other concentrations did not cause reliable changes.

Key words: Leucoagaricus macrorhizus, culture medium, extract of mycelium, peritoneal macrophages, oxygendependent metabolism.

Рецензент - проф. С.Є. Дейнека
Educational and Scientific Centre «Institute of Biology» of Taras Shevchenko National University (Kyiv)

Buk. Med. Herald. - 2013. - Vol. 17, № 1 (65). - P. 64-67

(C) О.М. Макаренко, М.П. Рудик, В.В. Позур,

М.М. Сухомлин, В.М. Святецька, Р.С. Довгий, 2013 